Fejzulla Shabani \& Demush Bajrami

\title{
TREATMENT OF THE ALBANIAN ISSUE AT THE LONDON CONFERENCE OF AMBASSADORS AND THE GEOPOLITICAL CONSEQUENCES FOR THE BALKANS
}

DOI: $10.2478 /$ seeur-2014-0010

The political and military changes that occurred at the beginning of the twentieth century - specifically, those changes which came as a result of the Balkan Alliance, and later the Balkan wars that aimed at the destruction of the Ottoman Empire-brought a new reality to the Balkans. This situation forced the Great Powers to be more present in the Balkans both because of their interests and in order to ensure that the geopolitical changes that happened would not exclude the Albanians. Unfortunately, the Albanians were not treated fairly and equally with the other people in the Balkans, yet the Albanian issue was to be a key factor for diplomatic confrontation and separation of interests in the Balkans. This situation reached its peak at the London Conference of Ambassadors, at which the Great Powers were divided into two parties: one group uniting Austria-Hungary, Germany and Italy, while the other group brought together Russia, France and England. As these groups debated their interests, a group of Balkan states stood in the background, intending to appropriate for themselves Albanian lands; they were against the independence of Albania, which was promulgated on 28 November 1912 in Vlora by Ismail Qemali, at which the Assembly formed a Temporary Government that was not only accepted by the Balkan states, but also by the Great Powers.

From the beginning of the First Balkan War, the Albanians attempted not to be part of the "tide of diplomatic games", for they perceived the intent of the Balkan states, who intended to take Albanian territories as war trophies. Considering that the Great Powers did not prevent a Balkan war, they (at least for a time) managed to prevent a confrontation between themselves which 
would bring about war in Europe. It was for this purpose that they began to think about organizing a Conference in London. This venture opened the way for the Foreign Minister of France, Poincarre, to circulate the idea of a conference: the idea at first was rejected by Vienna and Berlin, where it was believed that things might evolve in the Balkans in favor of their policy. Grey felt that with reforms in Istanbul, a major catastrophe in the Balkans might be avoided $^{1}$. On the other hand, France and Russia had previously harmonized their positions for a conference, and for this reason Russia demanded of Grey that he take the initiative to announce the Conference. Regarding the insistence of Russia, Grey would comment: "If Russia made this proposal, I believe it did so to earn credit as the initiator of the solution to preserve the peace in Europe and at the same time it would provide the Balkan allies with new benefits, but on the other hand, could potentially escalate into a European war for the Serbian harbor."2 It is important to note that England prior to the Conference had been active. Grey, on 21 November 1912, at a meeting in London with German ambassador Prince Lichnovský, analyzed the situation in the Balkans and the steps that should be taken. For this purpose he proposed three fundamental issues which the Great Powers should deal with: 1) the possibility of establishing an autonomous Albanian state and the borders it should have, 2) the methods and conditions of Serbian security in the Adriatic, and 3) the Aegean islands issue ${ }^{3}$. For this meeting he informed the representatives of Russia and France which had shared interests in the Balkans. Seeing the military situation taking place in the field, Vienna and Berlin agreed to hold a conference in London, and not (as proposed) in Paris. It is important to note that this conference was not convened after the war, but they began to work during the war. The proclamation of the independent state of Albania was a new phenomenon in the geopolitical changes in the Balkans at the start of this conference. A special feature that was not to benefit the Albanians at this conference is that the parties involved in the Balkan conflict had the right to present their views, but not participate in decisions; the Balkan states also retained the right to present their territorial claims at the conference, while Albania did not have that right, ${ }^{4}$ because it had not yet gained recognition as an independent state. From this we can conclude that Albania was handicapped in this regard, while other Balkan states did not hide their territorial claims for the Albanian state and Albanian lands. In this sense, the Great Powers used Albanian territories for their own interests, despite the fact

Gazmend Rizaj, Shqipëria e Sipërme 1800-1913 Prishinë 2011, p.335

2 Ibid.

3 Frashër Demaj Britania e Madhe dhe Cështja Shqiptare 1875-1913, Prishtinë 2011. p.258

$4 \quad$ Ibid., p. 257 
that Vienna and Rome (especially Vienna) defended their position of forming a newly independent state under the sovereignty of the Great Powers. In these circumstances, the question has always been what diplomatic stance the government of Vlora should have held, and what would be its potential to defend the territorial integrity of the Albanian state. It was impossible to ask for support from Russia, which was against the formation of the Albanian state; France also took the Russian side, and England adopted a neutral attitude. Thus the Vlora government could only rely upon the Tripartite Alliance led by Vienna, although even here there wasn't real sincerity on the question of the extension of the borders of the future Albanian state.

After much preparation and negotiations, on 17 December 1912 the London Conference of Ambassadors began. From the beginning of its work, the Conference was faced with the Albanian issue: based on diplomatic documents of the time, it is clear that at this conference the Albanian issue was treated in three segments: the political future of Albania, Albania's status, and assigning the borders of Albania ${ }^{5}$. With regard to the status of Albania they agreed to form an autonomous, neutral Albania under the sovereignty of the Sultan and under the guarantee of the six Great Powers. This decision had a special significance because it eventually extinguished the aspiration of those Balkan states that were against the formation of any kind of Albanian state; it also, however, extinguished all the hopes of Albanians to live in a state that would extend to all territories in which Albanians lived, a decision that was taken at the Assembly of Vlora. Despite this decision, Ismail Qemali, as a distinguished diplomat, addressed Grey with a telegram in which he noted: "Your Excellency it's my pleasure to express deep admiration and express my sincerest gratitude from the Provisional Government and the entire Albanian people for the decision taken under your chairmanship, in favor of Albania in the London Conference... Albanians have confidence, particularly in England, the hearth of civilization and the protection of peoples' rights to

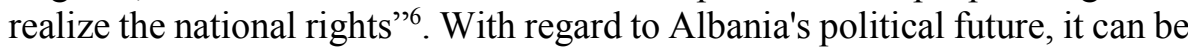
said that the London Conference took a decision to establish an Albanian state, but that it never recognized the government led by Ismail Qemali, and later they approved a foreign king. As for the third point, concerning the delimitation of the future state of Albania, the Great Powers in the south, north, and north-east perpetrated a great injustice by distributing Albanian lands among the Balkan states. This action opened the Albanian problem in the Balkans. It is of special importance to note here that despite these errors towards the Albanian people, again, the London Conference of Ambassadors

5 Fejzulla Shabani Shqiptarët e Maqedonisë 1908-1913 Tetovë 1996 p. 186

6 Gazmend Rizaj, Op.cit. p. 341 
was a high diplomatic meeting at which the Albanian issue was discussed directly by the major powers.

Because Vienna and Rome were allies - but also rivals for Albanian lands - at the Conference they adopted an attitude regarding the Albanian issue, of defending the creation of the Albanian state, but only for their own interests. They left aside discussion of the many Albanian settlements in Kosovo as well as in the eastern regions, both to promote their interests and also to some extent to satisfy the requirements of the Balkan states put forth by Russia. Therefore, we can note that among other points the Conference determined: 1) to refuse Serbia any access to the Albanian coast; 2) to refuse to transfer Shkodra to Montenegro and Vlora to Greece; 3) to insure the vitality of the existence of the Albanian state regarding its boundaries as much as they thought necessary"7.

As highlighted above, one of the issues discussed at the London Conference was the Albanian issue, especially the third point which concerned the delimitation of a future Albanian state. The Balkan states could not agree on this, so the conference began with proposals to draft maps, particularly on how and where to stretch the boundaries of the Albanian state; these proposals came from the Great Powers, the Balkan States, and the Government of Vlora. These early proposals indicate a strain in Austro-Russian relations, which protected the interests of the Balkan states. Analyzing the political-military and geopolitical circumstances in the Balkans in this period, some conclusions can be taken about these draft maps: 1) Albania had experienced five centuries of Ottoman rule and had been known only as an ethnic nation; 2) the Balkan Wars and the defeat of the Ottoman Empire had left the issue of the autonomy of Albania unsolved; 3) the Balkan allies had occupied a large part of the Albanian lands; and 4) the Balkan allies had strong support from the Russians and French ${ }^{8}$.

It is important to note that from the beginning of the Conference, the Great Powers let the Balkan states know that they supported an independent Albanian state, while its boundaries were to be discussed at the conference, which extinguished all their appetites for the dismemberment of Albanian lands, especially in Serbia. For this new reality in the Balkans Nicholas Pasic commanded Bogiçeviç from Athens to inform the Serbian delegation that "Serbia is oriented for dividing the territory of Albania, to obtain for Serbia

7 Ibid.

$8 \quad$ Ibid, p. 350 
access to the Adriatic Sea and Durrës." Seeing that the situation would evolve, on the issue of treatment of the future state border with the Balkan countries, several countries decided to address their demands to the Conference of Ambassadors, including Serbia (which demanded the east of Lake Ohrid, along the Black Drin River to the White Drin, which included Albanian-inhabited regions on the plain of Dukagjin, Kosovo and eastern parts), and Montenegro (besides requiring Shkodra territory, it also sought territory by the River Mat, or at least to the point where the Drin flows into the Adriatic Sea) ${ }^{10}$.

Of great importance for the treatment of the Albanian issue at this conference was the presentation of draft maps by the Great Powers, notably Vienna and Moscow's proposal that these two coordinated their interests in the Balkans and had no separate treatment of the Albanian issue, and the borders of a future Albanian state. From the beginning of the presentation of the draft map, Mensdorf presented Austro-Hungarian views regarding the future borders of the new Albanian state. According to him, those parts inhabited exclusively by Albanians should belong to Albania ${ }^{11}$. In the first proposal several Albanian settlements were not included in the Albanian state, but after consultation with Vienna Mensdorf presented the final draft of the Albanian state borders with Balkan states.

According to this proposal the northern boundary with Montenegro went along the river Buna, which left Gucia and Plava continuing into Peja, Gjakova, Prizren, inside Albanian state ${ }^{12}$. From Prizren to the territory of Lake

\footnotetext{
9 Dokumenti o Spolnoj Politici Kralevine Srbie 1904-1913, Letër e Pashiqit dërguar përfaqësuesit sërb Bogiçeviçit në Athinë më 24 november-7 december 1912

10 HHStA-PAA- Telegram i Mensdorf-it nga Londra më 4.I. 1913 dok. 5190

11 HHStA-PAA- Propozimi i Mensdorf-it, ambasador austro-hungarez në Angli më 2. XII. 1912 dok. nr.2

11 HHStA-PAA, Raport i Mensdorf-it dt. 18 XII. Dok. nr. 4957

11 Ibid.

11 HHStA-PAA- Raport i Mensdorf-it dt. 21 XII. 1912. Dok. 5012

11 Ibid.

11 HHStA-PAA- Raport i Mensdorf-it dt. 21 XII. 1912. Dok. 5012

11 Ibid.

11 HHStA-PAA- Raport i Mensdorf-it dt. 21 XII. 1912. Dok. 5012

11 Ibid.

11 HHStA-PAA- Raport i Mensdorf-it dt. 21 XII. 1912. Dok. 5012

12 Ibid.

12 HHStA-PAA- Raport i Mensdorf-it dt. 21 XII. 1912. Dok. 5012
} 
Ohrid and Prespa all settlements would belong to the Albanian state. This Austrian proposal actually represented the ethnic and historical reality of the future Albanian state, and was a fair treatment of the Albanian issue at this conference. But from the beginning this proposal was rejected by France and especially by Russia, where the Russian Ambassador Beckendorf stressed: "This issue cannot be solved just by considering the ethnic perspective however it is based; different interests should be taken into consideration, including those of the bordering states. ${ }^{13}$ " Faced with the ethnic principle, he pointed to the need for compromise to reach a satisfactory agreement that would take into account these very different interests. ${ }^{14}$ On the other hand, Russia did not hesitate to present a counter proposal to the conference that was contrary to Albanian interests and did not represent a principled approach by Russia. Under their proposal, the border should be the Drin River until where it flows into the sea, while in the east it should be where the White Drin joins the Black Drin, which meant that the territory from Lake Ohrid to Prizren should be left out of Albania ${ }^{15}$. Vienna's views were challenged by Sazanov particularly with regard to the cities of Prizren, Djakova, Peja and Debar, and it was proposed that these would belong to Serbia because they were vital areas for Serbia ${ }^{16}$. Contradictions between Austria and Russia over the treatment of the Albanian border issue also got worse, as can be seen in the meeting that Beckendorf had with the German ambassador Lihnovski, where the Russian representative emphasized that " we do not agree with the proposal of Vienna and if Vienna continues in this way, it may happen that the conference work will be stopped at which moment the chance of a war between Russia and Austro-Hungary would escalate ."17 Seeing that the situation might take an undesirable turn for the Great Powers, Germany's representative offered a proposal in which Debar and Djakova should remain with Albania. ${ }^{18}$ Russia disagreed and proposed that Shkodra remain with Albania, but that the Debar and Djakova settlements should belong to Serbia, because they were vital settlements for Serbia.

From this we can see how contentious the Albanian issue was at this conference, but at the same time how unprincipled the treatment of the

\footnotetext{
13 Ibid.

14 HHStA-PAA- Raport i Mensdorf-it dt. 21 XII. 1912. Dok. 5012

15 Fejzulla Shabani, op. cit p. 190

16 HHStA-PAA- Raport i Ambasadorit Turim nga Petrogradi drejtuar Berhtoldit më 4. I.1913

17 Arben Puto Pavarësia Shqipëtare dhe Diplomacia e Fuqive të Mëdha 1912-1914, Tiranë 1978. p. 199

18 Ibid.
} 
Albanian issue was, considering that its ethnic territories were treated like a market. To satisfy the requirements of the Balkan states, with the help of Russia, Vienna was persistent in defense of its project, but later alleged that in the interest of the larger issues would accept the disruption of Albanian lands, as desired and requested by the Balkan states. Seeing the situation that was taking place at the London Conference and how the Albanian issue was considered by the Great Powers, and in consideration of the demands of the Balkan states, on 2 January 1913 the Temporary Government of Vlora decided to present a memorandum on the issue of Albanian state borders to the Conference. This was based on factual arguments, but also was intended to promote developing relations with Balkan countries. In this memorandum it was noted: " Today as the final solution of the Balkan problem approaches, it is necessary and without delay that is be understood that the Albanian people could not endure their rights being sacrificed partially and the future of its independence be based upon the foundations of inconsistency...... a complete peace on the Peninsula cannot be imagined until the borders of any political entity are not inspired by the geographic and demographic borders of each state. Raising the voice on behalf of the Albanian people, the Interim Government represents the people, and therefore we have great confidence in the Great Powers, who will handle our issue in the correct way as with all the other people of the Balkans and with that equal treatment it will bring peace and stability in this region. Therefore we ask that for our territory and our state should not be allowed any change of borders and they should not be an object to unequal treatment at the conference. ${ }^{19}$

In the beginning of 1913, the London Conference brought nothing new, as contradictions raged around Serbia. January is the month in which Grey hoped to call for meetings with the sole purpose of achieving "a harmonization of the conflicting parties". The attitude of the English at this stage tried to be soothing so that this contradiction would not have consequences that could lead to a military conflict. Seeking support, on 9 January 1913 Gruic sent a letter stating that Serbia must have access to the "Serb coast"; Grey replied by asking Gruic what he meant by the words "Serb coast" and received an answer that in the Middle Ages it had belonged to the Serbs. ${ }^{20}$ Grey replied that the northern coast of France belonged to England but it is not considered British. At the conclusion of talks, Gruic urged greater support from London for the Serbian requirements, while Grey assured him that this support would be to

19 Qeveria e Përkohshme e Vlorës 1912-1914, Tiranë 1963 dok. nr. 135. 2 janar 1913 p. 98-100

20 Dokumenti o spolnoj politici... Raport i Gruiqit nga Londra dërguar Pashiqit më 9. I.1913 
the extent that all Balkan parties would be satisfied, but could not encompass all the Serbian requirements for the border issues of the future Albanian state $^{21}$. After this meeting, on 21 January 1913, the Serbian government sent a memorandum through Gruic to the Conference, concerning Albania. At first Pasic instructed Gruić to convince the Great Powers that this memorandum was also on behalf of the Balkan states. On the issue of the future Albanian state and its borders, Serbia was trying to convince the Conference of the presence of ethnic Serbs in Albanian lands, and to assert that the Serbian government did not agree to withdraw from Albanian lands occupied during the Balkan War, including cities like Prizren, Gjakova, Peja, Dibra and lake Ohrid. $^{22}$

Pasic further emphasized that, "in the interest of peace in Europe, the border between Albania and Serbia should be the one that is presented in the memorandum and in case our requirement are not fulfilled, the Serbian government will choose other ways to achieve its goals. ${ }^{23 "}$ According to him, the future Albanian state should include a narrow territory because only in this way could it exist and be protected by the Balkan states. ${ }^{24}$ Serbia's attempt to win more at the Conference by making threats can be seen very well in Mihajlovic's meeting in Rome with the Italian Minister San Giuliano, where Mihajlovic stated: " If Italy and Austria-Hungary have decided to form a new Albanian state it should be clear that without meeting the requirements and interests of the Serbian government there will not be peace in the borders. ${ }^{25}$ ", After the conflicts became too intense at the Conference regarding the future borders of the Albanian state, the British Ambassador in Vienna, Cartwright, expressed the opinion that the issue of the borders should be solved by the Hague Court based on first maximum and minimum line ${ }^{26}$ The government of Vlora, on 25 January 1913, sent the Conference an attachment to the previous memorandum, with which it attempted (with statistical data from south to north of the population) to persuade the Great Powers that the requirements of the Balkan states had nothing to do with the reality of their claims, but unfortunately the memorandum was not taken into consideration

21 Ibid.

22 Dokumenti o splonoj politici... Telegram i Novakoviçit dërguar Pashiqit nga Londra 26. XII.1912

23 Fejzulla Shabani, op.cit p. 195

24 Dokumenti o spolnoj poltici ... letër e Pashiqit dërguar qeverisë Ruse në Petrograd 27 XII. 1912 p. 622

25 Dokumenti o spolnoj politici... Letër e Mihajlloviçit nga Roma dërguar Pashiqit më 13 I. 1913 pp. $734-744$

26 Dokumenti o sponoj politici... Letër e Jovanoviçit nga Viena drejtuar Pashiqit më 15. I. 1913 
by the Great Powers. ${ }^{27}$ The major differences between Austria-Hungary and Russia continued during February and March 1913, and these disputes were of real harm to the treatment of the Albanian issue; as Mensdorf assured Berchtold, the real purpose of Russians is to receive something, as Grey confirmed for the first time and noted that perhaps we (Vienna) should relent with regard to Gjakova and Dibra. ${ }^{28}$ In another telegram on 13 February from Mensdorf to his ministry, he gave a warning that if Vienna would not yield, Austro-Russian relations will enter a very tense situation and that a war between them within a very short time was inevitable ${ }^{29}$. Despite these contradictions Grey, on 6 February 1913 called the upcoming Conference meeting in which he informed them about the Berlin proposal that Vienna agreed with and which London also supported, but this proposal was rejected by Russia; this meant that the treatment and discussion of the Albanian issue continued to have major objections and unfortunately all these went to the detriment of the Albanian interests, because they had no real allies in the ranks of the Great Powers.

In this very delicate period of the Conference, the diplomatic activity of the Balkan states, especially of Serbia, continued; Pasic instructed his representatives to make every effort to obtain for Russia more allies at the Conference, while on the other side there was not a lack of Russian diplomatic activity - especially Sazanov-emphasizing that Serbia and Russia made concessions regarding Shkodra, therefore could require from Vienna concessions in regard to Dibra and Djakova. From this it can be seen that the Albanian issue was addressed at the Conference, but without the consent and opinion of the Albanians. On the other hand Vienna stated that it had not yet said the last word about the north-eastern border of the Albanian state, and warned of further deepening of disagreement with consequences for international relations. The British Ambassador in Petrograd warned military circles of the danger of a European war. ${ }^{30}$ In early March 1913 disagreement between Russia and Austria-Hungary concerning the north-eastern border issue had reached its peak, when the London Conference of Ambassadors was discontinuing its work and European peace seemed threatened. AustriaHungary began military preparations, as did the Russians. ${ }^{31}$ To defuse this very delicate diplomatic and military situation, the idea arose to form a special commission that would deal with Serbian border issue with the Albanian state.

\footnotetext{
27 A.Q.SH. Kryesia e Qeverisë së Përkoshme të Vlorës. Veprimtaria diplomatike dok. 19

28 HHStA-PAA. Raport i Mensdorf-it dt. 15.II. 1913 dok. 5814

29 Arben Puto, op. cit. p. 199

30 Dokumenti o spolnoj poltici... Telegram i Popoviçit për në Beograd më 20.II. 1913

31 Liria e Shqipërisë. 8.III. 1913 Sofje
} 
Sazanov emphasized that, "if it comes to the formation of a committee for the issue of the north-eastern border, we should fight in not allowing the committee to take into the consideration the ethnographic data of these areas because in that case it would be in our disfavor, but rather there is a need to insist that the [committee] take into consideration the geographic element". ${ }^{32}$

The unfair treatment of the Albanian issue at the London Conference of Ambassadors was commented upon by knowledgeable observers of Albanian and Balkan issues. Edith Durham remarked of Tsarist Russia and its claims in the Balkans, that: "They (Albanians) knew well that while there are ten Serbians someplace, Russia swears that all provinces are Slavic." ${ }^{33}$ The Balkan affairs expert Alfred Rappaport noted: "Opposing arguments that had no support, once again pose lies and intrigue to the world. It is a nonsensical thing how they dared to deny Albania its necessary living areas and in this way put at risk universal peace, just because an Orthodox monastery was located in Gjakova, while in Dibra were some Serbian villages that remained in Serbia." 34 The newspaper "Pravda " wrote: " Serbia accepted the decisions of the Great Powers since it achieved its goals and it did not show anything, if it is dissatisfied and has not protested". ${ }^{35}$ In "Radničke novine", in an article entitled "Poor Albanians", it was observed that: "The bad luck of this people, from whom earlier a large territory had been taken by Greece, now even more is being stolen by Serbia and Montenegro. The remaining area left to the autonomy of Albania, its international, financial and military control was left to the Great Powers; this was made for a vital and healthy population in the Balkans - as Albanians are - and all this was done in the name of civilization." ${ }^{36}$ The end of March marks a negative turn by Austria-Hungary at the Conference, because Vienna on 20 March informed Grey that it no longer demanded that Gjakova and Dibra should belong to Albania, in order to achieve a compromise. The withdrawal of Vienna clearly shows that the Albanian issue was not treated equally and fairly in the Ambassadors Conference and until the end of the conference proceedings in July, it would not deal with the Albanian issue, but would appoint committees for setting boundaries with the Balkan states. Albania was assigned Prince Vid, which meant that the Conference did not accept Ismail Qemali's government as it emerged from the Assembly of Vlora. As noted above, Vienna announced the

32 Dokumenti o spolnoj politici... Letër e Popoviçit nga Petrogradi dërguar Pashiqit më 19. III. 1913

33 Fejzulla Shabani, op. cit p. 205

34 Alfrerd Rappaporti Rjedhat e punëve në Shqipëri Tiranë 1928. p. 41

35 Pravda 14. III. 1913

36 Radnicke Novine . 14 V.1913. Beograd 
withdrawal of its demand regarding Gjakova and asked for a guarantee to be given to the Albanian minority and in defense of their cultural freedom in the Balkan states, a proposal that was not accepted because Russia was against it. So, after much discussion and tension between Russia and Austria- Hungary on the issue of the Albanian state, they never asked Serbia to guarantee that Albanians in Serbia should be under the supervision of the Great Powers, because the Serbian government emphasized that this interfered in the internal affairs of Serbia. ${ }^{37}$ This implies that the Albanian territories at the Conference became an object of trade to the detriment of the Albanian people and in favor of Serbia. When Rappaport asked Berchtold for boundaries he replied: "All that you state is right, but can we protect them, because they are the cause of war." ${ }^{38}$ With this it may be understood that Vienna had done its utmost to protect the Albanian lands, but never attempted to consult with the Government of Vlora. The diplomatic war at the London Conference, as highlighted above, ended on 22 March 1913, because the meeting called by Grey, informed other representatives that Vienna had agreed to withdraw its demands. This was a great victory for Serbia and Russia in the Balkans, while a great injustice was done to the Albanian people; the Albanians lost half of their territory without being guilty at all, and without being part of the decision making. It can easily be said that this was a significant precedent in terms of international relations, and would have further consequences for the Balkans because the Albanians would never recover from this national injustice experienced at the London Ambassadors Conference.

Unfair decisions at the Conference, resulting in unequal and unfair treatment, infuriated Albanians both at home and abroad. The Vlora government undertook a diplomatic attempt, in which Ismail Qemali would lead a committee to visit the most important European centers and express opposition to London decisions, as well as inform them that the Albanians would never agree with these decisions. During April and May, Ismail Qemali along with Isa Boletini and Luigj Gurakuqin visited Rome, Vienna, Paris and London in the hope of finding support and to ameliorate the error committed in favor of the Serbs and Greeks. ${ }^{39}$ Even at the first meeting they had in Rome with San Giuliano, it became clear that the Albanian delegation would encounter resistance to its demands, because they had the impression that

37 Dokumenti o spolnoj politici... Telegram i Vesniqit nga Parisi dërguar Pashiqit më 24. III. 1913

38 Alfred Rappaporti- op.cit p.43

39 Thoma Murzaku Politika e Sërbisë kundrejt Shqipërisë gjatë luftës ballkanike. 19121913. Tiranë. 1987. Fq. 307 
these powers had decided against the Albanian people, and that it was hard for them to deal with the Albanian issue once again.

Even at the meeting with Berchtold in Vienna they were received without warmth, although here they thought they would find their biggest support, but it is important to note that despite the injustices at the Conference, Vienna still did not allow the full confiscation of Albanian lands and defended to the end the idea of creating an Albanian state in the Balkans.

The Albanian delegation expressed the belief that "hopes to save the territorial integrity of Albania were insufficient, despite the efforts Viennese diplomacy had made and was making". ${ }^{40}$ The same situation occurred in meetings that transpired in London and Paris, from which locations little support was expected; this was especially true of Paris, because the entire time at the Conference France had always supported the Russian position and that of the Balkan states, while England at least attempted to be neutral, but with a bias on behalf of the Balkan states. The Albanian delegation's activities in Europe were monitored by the Serbs, and this can be seen by the report that Jovanovoc sent to Belgrade from Vienna which stated: "Our delegation is very disappointed by these meetings, especially meetings in Rome and Vienna. ${ }^{41 "}$

On the basis of what was mentioned above, one may draw conclusions about the London Conference of Ambassadors and the geopolitical changes that have occurred in the Balkans in the interval of a century, particularly in relation to the Albanians. In the beginning of this century the Albanians represented a relevant factor in the Balkans, without damaging other Balkan people, but creating a new geopolitical reality in the Balkans and beyond. Despite positive evolutionary developments that occurred at the beginning of the century, these conclusions can be drawn for the treatment of the Albanian issue in the London Conference: 1) the Albanian government was not initially involved in diplomatic maneuvers in the Balkans and Albania, which lets us understand that they weren't equal with other Balkan state delegations; 2) The Albanian delegation did not officially go to London because the Albanian government wasn't invited to express its views on the issue that had to do with the future of the Albanian State; 3) even among the Albanian delegation there were disputes among Albanians; 4) the Albanian government relied more on Vienna than Rome, and they were right because only Vienna attempted to defend the Albanian territories until the end, although it never took into account the guidelines and the proposals of the Albanian delegation; 5) even

\footnotetext{
40 Arben Puto, vep. cit. p. 360

41 Dokumenti o spolnoj politici... Raport i Jovanoviçit nga Viena dërguar Pashiqit më 16.IV. 1913
} 
though the Balkan countries were not at the negotiating table, they had unreserved support from Paris and London, whereas Russia persistently protected Serbian demands; 6) in the end, it should be emphasized that despite the flaws and injustices that were done to the Albanians, this Conference had a special significance because it was the highest diplomatic forum of the Great Powers up to that time in which the Albanian issue was addressed. 


\section{References}

- Gazmend Rizaj, “Shqipëria e Sipërme 1800-1913”, Prishinë, 2011

- Frashër Demaj "Britania e Madhe dhe Cështja Shqiptare 18751913”, Prishtinë, 2011.

- Fejzulla Shabani "Shqiptarët e Maqedonisë 1908-1913", Tetovë, 1996

- Dokumenti o Spolnoj Politici, Kralevine Srbie 1904-1913, Letër e Pashiqit dërguar përfaqësuesit serb Bogiçeviçit në Athinë më 24 nëntor-7 dhjetor 1912

- HHStA-PAA- Telegram i Mensdorf-it nga Londra më 4.I. 1913 dok. 5190

- HHStA-PAA- Propozimi i Mensedorf-it, ambasador austro-hungarez në Angli më 2. XII. 1912 dok. nr.2

- $\quad$ HHStA-PAA, Raport i Mensdorf-it dt. 18 XII. Dok. nr. 4957

- HHStA-PAA- Raport i Mensdorf-it dt. 21 XII. 1912. Dok. 5012

- HHStA-PAA- Raport i Ambasadorit Turim nga Petrogradi drejtuar Berhtoldit më 4. I.1913

- Arben Puto "Pavarësia Shqipëtare dhe Diplomacia e Fuqive të Mëdha 1912-1914", Tiranë 1978

- Qeveria e Përkohshme e Vlorës 1912-1914, Tiranë 1963 dok. nr. 135. 2 janar 1913

- Dokumenti o spolnoj politici... Raport i Gruiqit nga Londra dërguar Pashiqit më 9. I.1913

- Dokumenti o splonoj politici... Telegram i Novakoviçit dërguar Pashiqit nga Londra 26. XII.1912

- Dokumenti o spolnoj poltici ... letër e Pashiqit dërguar qeverisë Ruse në Petrograd 27 XII. 1912

- Dokumenti o spolnoj politici... Letër e Mihajlloviçit nga Roma dërguar Pashiqit më 13 I. 1913

- Dokumenti o sponoj politici... Letër e Jovanoviçit nga Vjena drejtuar Pashiqit më 15. I. 1913

- $\quad$ A.Q.SH. Kryesia e Qeverisë së Përkoshme të Vlorës. Veprimtaria diplomatike dok. 19

- [28] HHStA-PAA. Raport i Mensdorf-it dt. 15.II. 1913 dok. 5814

- Dokumenti o spolnoj poltici... Telegram i Popoviçit për në Beograd më 20.II. 1913

- Dokumenti o spolnoj politici... Letër e Popoviçit nga Petrogradi dërguar Pashiqit më 19. III. 1913

- Alfrerd Rappaporti “Rjedhat e punëve në Shqipëri”, Tiranë 1928 
- Dokumenti o spolnoj politici... Telegram i Vesniqit nga Parisi dërguar Pashiqit më 24 . III. 1913

- Thoma Murzaku "Politika e Serbisë kundrejt Shqipërisë gjatë luftës ballkanike 1912-1913". Tiranë. 1987.

- Dokumenti o spolnoj politici... Raport i Jovanoviçit nga Vjena dërguar Pashiqit më 16 .IV. 1913 


\section{$* * *$}

Prof. Dr. Fejzulla Shabani is a professor at the State University of Tetova and South East European University with 19 years of academic experience. $\mathrm{He}$ is author of 3 books, has participated in several national, regional and international conferences and has published papers in scientific journals. Some of his papers include: "Kryengritja e Shtatorit" viti 1993 Revista Shkencore Jehona, "Rëndësia e shpalljes së pamvarësisë" viti 1992 Revista Shkencore Kërkime Historike, "Aleanca Ballkanike" viti 1999 Revista Shkencore Ghurmime Albanologiike, Diplomacia e Fuqive të Mëdha dhe cështja Shqiptare gjatë Luftërave Ballkanike, Tetovë 2012, Kontributi i Shqipëtarve të Viseve Lindore në Luftën për Shpalljen e Pamvarsisë, Studime Historike. Nr. 5-6, Shkup 2012, KONTRIBUTI DIPLOMATIK I HASAN PRISHTINES-SHKUP 2012.

$$
* * *
$$

Demush Bajrami is a Ph.D. candidate in the Faculty of Social Sciences, University of Tirana (Albania) working in the field of media politics. He is currently lecturing at the Department for International Communication and is also advisor to the Rector for Public Relations and Communication at the South East European University. During 1998-2002 he was a member of the parliamentary legislation of Macedonia. He has authored several research articles, including "The Balkans 100 years after the start of the First World War", and "The challenge of (non) implementation of the Ohrid Framework Agreement in the Republic of Macedonia." 